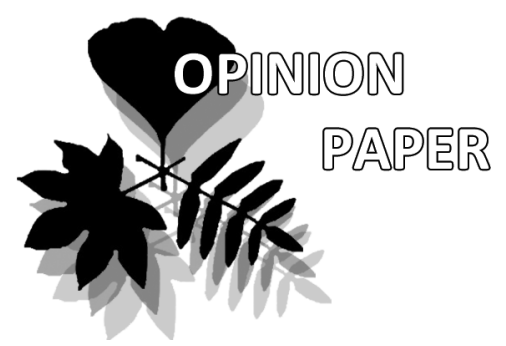

In memory of Valentin Krassilov,

Philosopher, Paleobotanist, and Friend

\title{
Epigenetic Theory of Evolution in Brief
}

\author{
Alexandr P. Rasnitsyn
}

Alexandr P. Rasnitsyn

e-mail: alex.rasnitsyn@gmail.com

A.A. Borissiak Palaeontological Institute Russian Academy of Sciences Moscow 117997, Russia

Department of Palaeontology

Natural History Museum

London SW7 5BD, UK

Manuscript received: 19.05.2015

Review completed: 04.08.2015

Accepted for publication: 07.08.2015

Published online: 11.08.2015

\begin{abstract}
A B S T R A C T
Genetics predicts features of evolutionary processes such as qualitative correspondence between (i) genotypic and phenotypic changes in an individual, (ii) genotypic and phenotypic population diversity and (iii) speed of changes in population gene pool on the one hand and tempo of evolution of the other. These predictions contradict observations, that are resolvable based on epigenetic rather than genetic approaches. Epigenetic theory deals with the relatively stable ontogenetic mechanisms and processes (creods) interconnected in an entire, holistic, evolutionary balanced system, a shift of which beyond evolutionary elaborated limits is by no means a trivial task (principle of the adaptive trade-off). Genetic mechanisms play an important role as switches and tuners which regulate interactions of creodes: they represent more labile evolutionary phenomena compared to the epigenetic system. Patterns of evolution are considered as specific consequences of epigenetic mechanisms.
\end{abstract}

Ke y w o r d s : stability of ontogenesis, adaptive trade-off, evolutionary stasis, Permian/ Triassic biotic crisis

\section{P E 3 Ю M E}

Расницын А.П. Эпигенетическая теория эволюции на пальцах. Генетика предсказывает свойства эволюционного процесса (качественное соответствие) а) генотипических и фенотипических изменений организма, б) генотипического и фенотипического разнообразия популяций и в) скорости изменения генофонда популяции (скорости эволюции), которые не подтвержАаются наблюдениями. Эти противоречия гораздо Аучше объясняются в рамках эпигенетической теории эволюции, гАе основным содержанием эволюции предстает система относительно устойчивых онтогенетических механизмов и процессов (креодов), сопряженных в целостную, эволюционно сбалансированную систему, изменение которой представ яет нетривиальную задачу (принцип адаптивного компромисса), тогАа как собственно генетические механизмы играют роль переключателей и модификаторов взаимодействия креодов и эволюционно более мабильны. Рассмотрены особенности эволюционного процесса как специфические результаты действия эпигенетических факторов.

К $\boldsymbol{\Lambda}$ ю че в ы е с $\boldsymbol{\Lambda}$ о в а : стабильность онтогенеза, аАаптивный компромисс, эво$\Lambda$ юционный застой, биотический кризис перми и триаса
It is customary to think that natural changes in the hereditary machinery (mutations, recombinations) cause particular changes in an organism affecting its survival. This generates selection that modifies both composition and other features of a population. Accumulation of these modifications appears as evolution. This simple and clear scheme opens a space for testable predictions. Indeed, assuming that the genotypical (cryptic) and phenotypical (open to observation and to selective agents) modifications are essentially interconnected means that these should be correlated in space and time both at individual and at higher levels, including the process of evolution. Mutations and their phenotypical manifestations should be coordinated qualitatively (the environmentally caused non-heritable phenotypical variations being set aside). This should cause at least a rough correlation between the genetical and phenetical diversity of populations. Equally, a rough correlation of tempos of genotypical and phenotypical evolution should be expected. And finally, speed of evolution of a particular group (i.e. a population or a taxon) should be limited by their genetic constitution. In other words, we are to expect the faster the evolutionary process, the higher the population size and fecundity and the shorter the generation time.

It is known well and for long time that not a single element of these predictions comes true (summarized Rasnitsyn 1987, 2006). At the level of individual, specific effect of practically any mutation can be phenocopied that is repeated under impact of various even though also specific environmental agents like higher or lower temperature, or a particular chemical applied in a particular moment of development. The phenomenon of phenocopying is described in most genetic textbooks and need not be referred to here. 
At the level of population, a discordance of genotypical and phenotypical diversity is still more apparent. The classical work by S.S. Chetverikov and his school revealed a huge genetic diversity hidden under highly monomorphic and stable wild phenotype of the Drosophila fly, with this stability and monomorphy being not a simple result of permanent scrapping of phenotypical deviations, for sophisticated selective contrivances found necessary to overcome the stability of wild phenotype (Rautian 1993). Essentially the same phenomenon can be referred to where the inference is that the population gene pool evolves more quickly than that of the phenotype (e.g., Schmalhausen 1983: 65).

At the evolutionary time scale, it holds true that rapidly propagating organisms with big populations can really evolve quickly. It can require only a brief period to generate a new microbe strain, whereas years are necessary to produce a new strain of cattle. That is reverse in the real evolution where the highest rate is characteristic of whales and elephants, and lowermost of microorganisms, so that the half-modern fauna (with half of constituent species being living and another half extinct) is 200000 years in elephants and other big animals, and 15000000 years in algal diatoms (see Rasnitsyn 1987, 2006, for details and references).

The above failure of predictions by the genetic theory of evolution does not affect the genetic basis of the theory: these persist perfectly unquestionably. The problem is that the immense success of genetics just overshadowed the failure of the genetic theory to explain evolutionary phenomena and prevented the subject from addressing actual issues of evolutionary biology (Rasnitsyn 2014). However, ignoring a problem does not assist with its resolution (cf. also Krassilov 2009). Attempts to consider in an open-minded way the discordance between genetic predictions and observed features of evolution resulted in a proposal of the epigenetic theory of evolution which shifts attention from genetics to a higher and particularly the ontogenetic level of organization of living beings (Shishkin 1984, 1987, 1988 a, b, 2006, Rasnitsyn 1987, 2002, 2006, 2008, Rautian 1993, Vasiliev 2005). Worth mentioning is that molecular epigenetic processes (methylation etc.) operate at a different level and so can hardly concern the epigenetic theory of evolution.

The most striking and apparent contradiction between genetic predictions and evolutionary observations is the aforementioned rapid evolution of the largest mammals and correspondingly slow changes in microorganisms. Having no doubts about the correctness of the genetic data we should conclude that the genetically limited evolutionary potential of whales and elephants is sufficient even for their highest obereved rates. Indeed, humans are able to extensively modify cattle and horses in a few decades, whilst elephants and whales had tens and hundreds thousand years to evolve. In any case, the above makes apparent that the question is not why evolution goes so quickly in big mammals: it is why other organisms evolve so slowly. The problem is not evolution but stasis.

Hence it becomes crucial to question, which agents slow down the evolution. To identify them, let us start with the first of above failed predictions. If a specific morphogenetic effect of a mutation may originate as a phenocopy (passing genotype), and if the organism presents a complicated re- sponse to a variety of simple albeit specific stimuli, then the morphogenetic response is programmed as such and so represents an essentially independent process. Any textbook on embryology, particularly vertebrate embryology demonstrates that development represents an arrangement of integrated and well tuned morphogenetic processes, so that a group of cells develops on a nerve tube, an eye, an ear, or in a limb depending of a particular simple agent affecting it in a particular moment of time. These relatively stable and independent processes called creodes are numerous and diverse. Their realization in a successful ontogenesis needs the finest adjustment, and every modification needs re-adjustment, reorganization of all numerous interconnections and interactions between creodes (and still more so within creodes). This makes crucial a function of connecting of individual creodes into the entire ontogenetic process to secure its efficiency and stability. Moreover, the development should be equifinal, that is, to secure development of a viable organism in spite of inescapable internal errors and external disturbances. It is the genetic machinery which takes the function of creode coordination and control of their interaction including the switch of development from one creode to another in a proper place and time. This machinery is understandably more easy to adjust and modify when necessary compared to the creodes themselves which are particularly change resistant.

The important inference from the above is that any evolutionary change is accompanied by ontogenetic transformation affecting all its complicated interconnections and interactions which extends far beyond a simple modification of a selected character. It is well known from the practice of selection, that a successful selection for a particular character results in numerous correlated, almost invariably unfavorable changes of other characters. To overcome the resultant loss of viability that quickly nullifies the positive effect of a previous selection represents the most difficult task of a breeder. All features and functions of organism are interconnected and interdependent, and each of them is under a permanent selective control, which makes problematic, to say the least, any successful modification of organization beyond the evolutionary stabilized limits of individual variability. This looks like a task to modify (but not to replace, for evolution lacks any spares) a car motor component on the run. This effect was called the adaptive trade-off which can be defined as a contradiction between a necessity to change and necessity to keep adaptive all selectively the controlled structures and functions.

It is the adaptive trade-off which can be considered as a probable mechanism of the evolutionary stasis, at least until a better candidate is proposed. The adaptive trade-off is probably responsible also for the phenotypic stability as compared to the genotypic one, for the phenotype is directly selectively controlled, and genotype indirectly so. It helps additionally to understand why rapidly propagating organisms are not necessarily evolving faster than slowly breeding ones. This is a good result even if not as good as we need. This is not a whole story, however.

Epigenetic theory of evolution is only starting its development and so far has had insufficient time to consider all relevant issues. At the same time, there are some real 
achievements. It is possible to consider why the genetic potential of population to change (fecundity, generation time, etc.) does not control speed of the long scale evolution: it is because there is a forceful agent braking evolution, the adaptive trade-off. It is not a trivial question as to how an elaborated adaptive trade-off can be overcome or, in other words, how a group can be changed beyond the limits of trivial (evolutionary secure) population diversity. Indeed, no environmental filtering can help, for a population would simply go extinct rather than change because of limitations of the trade-off. Environmental softening is also of no help, for in favorable environments the enhanced reproduction will quickly (at an ecological time scale) raise the population density and the density dependent mortality up to the mortality values characteristic of normal and unfavorable life conditions. Trade-off stability will remain unshaken.

The adaptive trade-off opens a way for evolutionary changes only under rather strict and specific circumstances. This occurs when the adaptive (selective) control of organization turns to be strictly unbalanced or one-sided. For instance, when a population finds itself as an island lacking predators and parasites, its main problem might be only to learn consuming new food, and this new adaptation can be gained at expense of those that have lost their relevance in new environments. As a result, the old trade-off will be broken and another should be constructed anew. The above is not an exotic instance, and the island explosive diversification is a commonplace event. Intrusion into an empty ecological space represents another and equally well known evolutionary event characteristic of explosive diversification. It is another thing that the due course of reproduction and explosive diversification of the intruders (and other intruders, if any), the space becomes less empty, conditions harsher, and trade-off more strictly controlled. Nevertheless the chance is left for the invader to elaborate its organization sufficiently to survive and, in lucky circumstances, even to intrude successfully into further territories and ecological spaces.

The puzzle why big and slow breeding animals are evolving so quickly in contrast to smaller and fast reproducing ones is only partially explained. It is understandable now that genetic limitations of evolutionary pace are irrelevant being sufficient for anomalously quick evolution of whales and elephants. What is the agent accelerating their transformation or, rather, variously decelerating the evolution of other taxa? For the present, I can indicate at least one agent responsible in part for the paradoxical speed distribution across the living world, the very body size which is known to correlate at an extent with the complexity of organisms. Particularly indicative is the observation that big and small mammals differ markedly in their pace of evolution (two or more times different; Rasnitsyn 1987, 2006) in spite of a comparable level of complexity. The reason is apparent at least in one respect: when environments change, a mouse still can locate a refuge while an elephant faces a choice either to go extinct or to break the adaptive trade-off. Still more this holds true for a bug, let alone microorganisms. This is certainly not to say that the paradox of evolutionary speed is now resolved, but it is a step in that direction. And there is no reason not to expect further progress.

The expected progress of the epigenetic theory of evolution really occurs even though arising from an unexpected source. Here I mean recent paleontological observations which are hardly explainable without addressing to the epigenetic effects (Rasnitsyn 2012, Aristov \& Rasnitsyn 2015). It was found that the greatest biotic event of the Phanerozoic (last 570 million years), called informally $\mathrm{P} / \mathrm{T}$ event and occurred at the boundary of Paleozoic and Mesozoic (that is, Permian and Triassic), probably was not a result of a global extinction catastrophe. At least in case of the insects, the group accounting for a half of global biodiversity, extinction rates were of background values during all the Middle and Late Permian including the very $\mathrm{P} / \mathrm{T}$ transition (lower than during the Carboniferous and Early Permian). Biodiversity crisis did exist during the Middle and Late Permian, but the first, was completed by the basal Triassic, and the second was caused by the decline of the insect diversification and not by increased rate of extinction. And this was not a unique phenomenon: similarly a shorter time of depressed diversification occurred before the end of Carboniferous, again before an important boundary in insect evolution when the most prolific insect groups (Holometabola and Hemiptera) appeared.

The above implies that the diversification and not extinction rate is likely a critical factor of the biodiversity dynamics, that is, biodiversity is governed primarily internally (biologically) rather than externally (environmentally). The crucial question appears to be which agent could control the diversification rates and what can pose limits on it. For the present, the only agent that is known to be predisposed to depress evolution in the long run, is the adaptive tradeoff, that is, deep interconnection and coordination of all developmental and functional machinery in an organism. This makes any particular modification beyond the evolutionary established limits of individual variability a risky task of transforming an entire organization, a transformation of one well balanced trade-off into another one, also well balanced. This transformation, in order to be successful, requires special conditions which are not very common (see above), otherwise environmental changes would only lead to extinction. If a biota persists in more or less stable environments, it becomes naturally adapted to this stability and enriched with perfectly balanced forms particularly resisting modification. Diversification (origin of new taxa) becomes depressed, and even a background level of extinction (caused by the background level of environment disturbance) is not compensated by diversification. Biota will grow more and more impoverished until the strength of reciprocal control by the ecosystem partners weakens sufficiently to make it easier to overcome the adaptive trade-off and so to trigger new and explosive diversification.

The above effect of accumulation of taxa "stiffen in their perfection" was proposed as a hypothetical and rather exotic mechanism (Rasnitsyn 2002: 20). However, this mechanism appears to be the only possibility to explain the phenomenon of depressed diversification as combined 
with the background extinction rate (Rasnitsyn 2012), particularly when this phenomenon is found to occur regularly in evolution (Aristov \& Rasnitsyn 2015). It is a tempting and inspiring task now to test if this mechanism is responsible at least in part of other global biodiversity crises.

\section{ACKNOWLEDGEMENTS}

I am thankful to Dr Sofia Barinova (Institute of Evolution, University of Haifa, Israel) and Eugenia Bugdaeva (Institute of Biology and Soil Science, Far Eastern Branch, Russian Academy of Sciences, Vladivostok), for kind invitation to participate to the V.A. Krassilov memorial issue.

\section{LITERATURE CITED}

Aristov, D.S. \& A.P. Rasnitsyn 2015. Insects in the Paleozoic: milestones. Priroda 5:64-67 (in Russian). [Аристов А.С., Расницын А.П. 2015. Насекомые в палеозое: этапы большого пути // Природа. № 5. С. 64-67].

Krassilov, V.A. 2009. Paleontology and paradigms of modern natural sciences. Ekologiya i Zhižn' 5(90): 6-12 (in Russian). [Красилов В.А. 2009. Палеонтология и параАигмы современного естествознания // Экология и жизнь. № 5(90). С. 6-12].

Rasnitsyn, A.P. 1987. Tempo of evolution and evolutionary theory (hypothesis of the adaptive compromise). In: Evolution and biocenotic crises, (L.P. Tatarinov \& A.P. Rasnitsyn, eds.), pp. 46-64, Nauka, Moscow (in Russian). [Pacницын А.П. 1987. Темпы эволюции и эволюционная теория (гипотеза аАаптивного компромисса) // ЭвоАюция и биоценотические кризисы / под реА. А.П. Татаринова и А.П. Расницына. М.: Наука. С. 46-64].

Rasnitsyn, A.P. 2002. Evolutionary process and methodology of systematics. Trudy Russkogo entomologicheskogo obshchestva 73:1-107 (in Russian). [Расницын А.П. 2002. Процесс эволюции и методология систематики // Труды Русского энтомологического общества. Т. 73. 107 с.].

Rasnitsyn, A.P. 2006. Ontology of evolution and methodology of taxonomy. Paleontological Journal 40 (Suppl. 6): S679-S737.

Rasnitsyn, A.P. 2008. Theoretical base of evolutionary biology. In: V.V. Zherikhin, A.G. Ponomarenko \& A.P. Rasnitsyn. Introduction into paleoentomology, pp. 6-79, KMK Sci. Press Ltd., Moscow (in Russian). Расницын А.П. 2008. Теоретические основы эволюционной биологии // Введение в палеоэнтомологию / Жерихин В.В., Пономаренко А.Г., Расницын А.П. Москва: КМК. С. 6-79].

Rasnitsyn, A.P. 2012. When the life was not going to die. Priroda 9:39-48 (in Russian). [Расницын А.П. 2012.
Когда жизнь и не думала умирать // Природа. № 9. C. 39-48].

Rasnitsyn, A.P. 2014. Evolutionary theory: the current state. Paleontologicheskii Zhurnal 48(1):1-6. [Расницын А.П. 2014. Эволюционная теория: современное состояние // Палеонтологический журнал. № 1. С. 3-8].

Rautian, A.S. 1993. On the nature of genotype and heredity. Zhurnal obshchei biologii 52(2):132-149 (in Russian). [Раутиан А.С. 1993. О природе генотипа и наслеАственности // Журнал общей биологии. Т. 52. № 2. C. 132-149].

Shishkin, M.A. 1984. Individual development and natural selection. Ontogenez 15(2):115-136 (in Russian). Шишкин M.А. 1984. Индивилуальное развитие и естественный отббор // Онтогенез. Т. 15, № 2. С. 115-136].

Shishkin, M.A. 1987. Individual development and theory of evolution. In: Evolution and biocenotic crises (L.P. Tatarinov \& A.P. Rasnitsyn, eds.), pp. 76-124, Nauka, Moscow (in Russian). Шишкин М.А. 1987. Индивидуальное развитие и эволюционная теория // Эволюция и биоценотические кризисы / под реА. А.П. Татаринова и А.П. Расницына. М.: Наука. С. 76-124].

Shishkin, M.A. 1988 a. Evolution as epigenetic process. In: Modern paleontology, Vol. 1, (V.V. Menner \& V.P. Makridin, eds.), pp. 142-169, Nedra, Moscow (in Russian). [Шишкин M.A. 1988 а. Эволюция как эпигенетический процесс // Современная палеонтология / под реА. В.В. Меннера и В.А. Макридина. Т. 1. М.: НеАра. С. 142-169].

Shishkin, M.A. 1988 b. Pattern of evolution of ontogenesis. In: Modern paleontology, Vol. 1, (V.V. Menner \& V.P. Makridin, eds.), pp. 169-209, Nedra, Moscow (in Russian). Шишкин М.A. 1988 b. Закономерности эволюции онтогенеза // Современная палеонтология / под реА. В.В. Меннера и В.А. Макридина. Т. 1. М.: Недра. C. 169-209].

Shishkin, M.A. 2006. Individual development and lessons of evolutionistics. Ontogenez 37(179-198) (in Russian). ШШишкин М.А. 2006. ИнАивиАуальное развитие и уроки эвомюционизма // Онтогенез. Т. 37. С. 179-198].

Shmalgauzen, I.I. 1983. Selected papers. Pathways and patterns of the evolution processes. Nauka, Moscow, 360 pp. (in Russian). Шмальгаузен И.И. 1983. Избранные труды. Пути и закономерности эволюционного процесса. М.: Наука. 360 с.].

Vasiliev, A.G. 2005. Epigenetic base of phenetics: towards the population meronomy. Akademkniga, Ekaterinburg. 640 pp. (in Russian). [Васильев А.Г. 2005. Эпигенетические основы фенетики: на пути к популяционной мерономии. Екатеринбург: Академкнига. 640 с.].

\begin{abstract}
Alexandr Rasnitsyn:
I cannot recollect when I first met Valentin: it was too long ago. Can I only say that apparently we felt drawn to each other from the very beginning. We met at conferences, then worked in one institution, participated in join projects, sometimes running to field trips jointly, I was his guest in Haifa for days. I always admired the width and depth of his knowledge, his deep entry in each field of inquiry, his boldness in developing and presenting his ideas regardless of scientific mainstreams. Yet I never really understood him well. This is because he was, in my eyes at least, prima facie a humanist rather than naturalist (as myself). No question, he was a great paleobotanist, general biologist and geologist. Still he was The Philosopher first of all, also with a keen understanding of the deep meanings of ancient literature: and his explanation of philosophy of chivalry is still in my memory. It is possible to keep writing, but I prefer to say simply that we have lost a great man and a scientist.
\end{abstract}

